\title{
Nitrogen and phosphorus on crambe development after off-season corn cultivation
}

\section{Nitrogênio e fósforo no desenvolvimento do crambe após milho safrinha}

\author{
Eduardo Obadowski LEDUR ${ }^{1}$; Lucia Helena Garófalo CHAVES $^{2}$; Josely Dantas FERNANDES ${ }^{3}$ \\ 1 Doutor; Universidade Tecnológica Federal do Paraná. Email: obadowski@uftpr.edu.br \\ ${ }^{2}$ Autor para correspondência: Eng. Agrônomo; Doutora; Universidade Federal de Campina Grande; Av. Aprígio Veloso, \\ 882. CEP.58429-140; Campina Grande, PB. Email: ingarofalo@hotmail.com \\ ${ }^{3}$ Doutor; Universidade Estadual da Paraíba. Email: joselysolo@yahoo.com.br
}

Recebido em: 20-02-2015; Aceito em: 02-11-2015

\begin{abstract}
Crambe, a winter crop, is used as forage in crop rotation and soil coverage, besides being a raw material source for biodiesel production. However, information on the crop nutritional requirements in Brazil is scarce. The objective of this study was to evaluate nitrogen $(0,30,60,90$ and120 kg ha-1) and phosphorus $(0,50,75$, 100 e $125 \mathrm{~kg} \mathrm{ha}^{-1}$ ) fertilization effects on crambe development and N, P and K leaf contents in an Eutrophic Red Latosol after off-season corn cultivation, at an experimental field in the state of Paraná, Brazil. A randomized block design was used in the experiment, with three repetitions in a $5 \times 5$ factorial. Nitrogen and phosphorus application and $\mathrm{N}$ and $\mathrm{P}$ interaction increased the number of branches and grains. Plant dry matter and potassium leaf content were influenced by $\mathrm{N}$ application. Plant height was influenced by phosphorus application and $\mathrm{N}$ and $\mathrm{P}$ interaction. Leaf nitrogen and phosphorus were not affected by nitrogen and phosphorus application in the soil.
\end{abstract}

Additional keywords: Crambe abyssinica H.; nitrogen fertilizer; oleaginous plant; phosphate fertilizer; production components.

\begin{abstract}
Resumo
Crambe, uma cultura de inverno, é utilizada como forrageira na rotação de culturas e na cobertura de solos e fonte de matéria-prima para a produção de biodiesel; no entanto, as informações sobre as exigências nutricionais para esta cultura, no Brasil, são escassas. Objetivou-se com este trabalho avaliar os efeitos da adubação nitrogenada $\left(0 ; 30 ; 60 ; 90\right.$ e $\left.120 \mathrm{~kg} \mathrm{ha}^{-1}\right)$ e fosfatada $\left(0 ; 50 ; 75 ; 100\right.$ e $\left.125 \mathrm{~kg} \mathrm{ha}^{-1}\right)$ no desenvolvimento e os teores foliares de N, P e K do crambe em Latossolo Vermelho eutroférrico, após o cultivo de milho safrinha, em um campo experimental no Estado do Paraná. O delineamento experimental foi o em blocos casualizados, com três repetições, em esquema fatorial $5 \times 5$. As aplicações de nitrogênio, de fósforo e a interação de $\mathrm{N}$ com $\mathrm{P}$ aumentaram o número de ramos e de grãos. A massa seca das plantas e o teor foliar de potássio foram influenciados pela aplicação de N. A altura das plantas foi influenciada pela aplicação de fósforo e pela interação de $\mathrm{N}$ com $\mathrm{P}$. O nitrogênio e o fósforo foliar não foram influenciados pela aplicação de nitrogênio e fósforo no solo.
\end{abstract}

Palavras-chave adicionais: adubação fosfatada; adubação nitrogenada; componentes de produção; Crambe abyssinica $\mathrm{H}$.; planta oleaginosa.

\section{Introduction}

Crambe (Crambe abyssinica H.) is an oleaginous plant belonging to the Cruciferae family, which is native to the Mediterranean region, from Ethiopia to Tanzania, although it is grown in tropical and subtropical regions. It can be said that crambe is a winter species, which is sown in Brazil after soybean harvest, from March to May (Pitol, 2008). According to Falasca et al. (2010), crambe optimum temperature during the growing season is between 15 and $25^{\circ} \mathrm{C}$, although it is capable of tolerating temperatures of up to $-6{ }^{\circ} \mathrm{C}$ for a few hours without significant damage.

In Brazil, research on crambe crop began in the mid-90s, more precisely in 1995 , in the munici- pality of Maracajú, Mato Grosso do Sul State. Initially, plant behavior was evaluated as soil cover. Later, crambe was used by farmers in the region as alternative forage in crop rotation and soil cover for no-tillage system during winter (Pitol et al., 2010a). In addition, crambe is a plant with great potential to be grown for the purpose of biodiesel production, as its oil is not recommended for human consumption, due to having high erucic acid content (50-60\%). Crambe oil extracted from seeds can be used as industrial lubricant and corrosion inhibitor. In addition, it can also be used in synthetic rubber, plastic rubber, nylon, adhesives and electrical insulation manufacturing (Pitol, 2008). Cultivation is fully mechanized, and the same equipment of traditional crops can be used to 
produce the grain (Medeiros, 2007).

Crambe, like other plants, needs nutrients such as nitrogen, phosphorus and potassium (NPK). Nitrogen, for example, is an essential element for plant growth, chlorophyll and enzyme activity, as it stimulates root nutrient uptake, increasing plant growth. Phosphorus stimulates root development, flowering and seed formation, accelerating physiological maturity and increasing cold resistance and yield (Malavolta et al., 1997).

Crambe response to soil fertility is similar to that of small grains (Knights, 2002), such as rapeseed (Brassica napus L. and Brassica rapa L.) and mustard (Brassica juncea L.). However, there are no specific recommendations for this crop. Therefore, research on this subject is needed.

In this context, this study aimed to evaluate the effect of $\mathrm{N}$ and $\mathrm{P}$ doses in $\mathrm{N}, \mathrm{P}$ and $\mathrm{K}$ leaf contents, growth and yield of crambe cultivated after off-season corn crop in the west of Paraná State.

\section{Material and methods}

Research was conducted in field, at a farm located in the municipality of Serranópolis do Iguaçu, Paraná (5402 'W, 2524' S; 300 m altitude), in an Eutrophic Red Latosol (ERL) with $730 \mathrm{~g} \mathrm{~kg}^{-1}$ clay, $160 \mathrm{~g} \mathrm{~kg}^{-1}$ silt and $110 \mathrm{~g} \mathrm{~kg}^{-1}$ sand. The study area has been cultivated for about 15 years in a no-tillage system with crop rotation (soybean in summer and corn in winter). However, crambe was grown in conventional system. The climate is humid subtropical mesothermal. During the trial period, from July to November 2012, mean rainfall data corresponded to $125 \mathrm{~mm}$ (July), zero $\mathrm{mm}$ (August), $50 \mathrm{~mm}$ (September), $262 \mathrm{~mm}$ (October) and $75 \mathrm{~mm}$ (November); it was an atypical year, as rains usually occur in August; and minimum and maximum temperatures ranged from 15 to $23^{\circ} \mathrm{C}$ and from 20 to $28^{\circ} \mathrm{C}$, respectively.

Before sowing of FMS Brilhante crambe cultivar, chemical properties of the soil sample, collected in the surface layer $(0-0.20 \mathrm{~m})$, were determined according to Embrapa (2009), with the following results: organic matter $(\mathrm{OM}), 30.88 \mathrm{~g} \mathrm{dm}^{-3}$; $\mathrm{pH}\left(\mathrm{H}_{2} \mathrm{O}\right), 5.3 ; \mathrm{P}, 18.8 \mathrm{mg} \mathrm{dm}^{-3} ; \mathrm{K}, \mathrm{Ca}, \mathrm{Mg}$ and $\mathrm{H}+\mathrm{Al}$, 2.2, 58.7, 28.2 and $42.8 \mathrm{mmolc}_{\mathrm{c}} \mathrm{dm}^{-3}$, respectively; base saturation, 67.5\%; and $\mathrm{S}^{-\mathrm{SO}_{4}}{ }^{-2}, \mathrm{Cu}, \mathrm{Fe}, \mathrm{Mn}$ and $\mathrm{Zn}$, $6.67,8.19,32.0,112.0$ and $1.36 \mathrm{mg} \mathrm{dm}^{-3}$, respectively.

The study consisted of a randomized block experimental design with three repetitions, in a $5 \times 5$ factorial, in which factors were phosphorus $\left(\mathrm{P}_{2} \mathrm{O}_{5}\right)(0$, $50,75,100$ and $\left.125 \mathrm{~kg} \mathrm{ha}^{-1}\right)$ and nitrogen doses $(\mathrm{N})(0$, $30,60,90$ and $120 \mathrm{~kg} \mathrm{ha}^{-1}$ ), totaling 75 experimental units. Each plot was 5 meters long and 4 meters wide $\left(20 \mathrm{~m}^{2}\right)$, with a one meter spacing between plots.

Crambe was mechanically sown in July 2012 , with a spacing of $0.40 \mathrm{~m}$ between rows. $\mathrm{P}_{2} \mathrm{O}_{5}$ and $\mathrm{N}$ doses were added in superphosphate and urea form, respectively. Before crambe sowing, the soil was fertilized with $40 \mathrm{~kg} \mathrm{ha}^{-1} \mathrm{~K}_{2} \mathrm{O}$ (potassium chloride), in which the total dose of $\mathrm{P}_{2} \mathrm{O}_{5}$ treatments and half the dose of $\mathrm{N}$ treatments was applied in the sowing furrow. The other $\mathrm{N}$ half was applied in cover, in the thirtieth day after emergence. As the soil was wet and it rained after fertilizer application, there was no need to carry out irrigation.

In the inflorescence period, about 70 days after sowing, the third leaf from the apex to the base was collected, with around 30 plants being randomly selected in each plot. Leaves were washed and dried to constant weight in a forced air dryer at $70^{\circ} \mathrm{C}$. After drying, grinding and digestion, $\mathrm{N}, \mathrm{P}$ and $\mathrm{K}$ concentrations were determined according to Malavolta et al. (1997).

During harvest, which was conducted manually in 5 central rows at 95 days after emergence (November 2012), ten plants were collected randomly in each plot $(2 \times 3 \mathrm{~m})$, in order to determine plant height (distance between soil level to the plant apex). In the same period, grains were harvested and threshed manually, in order to determine the 1000grain weight and grain yield. Data were subjected to analysis of variance by $\mathrm{F}$ test. When significant effects were found, data were compared by regression analysis using the SISVAR statistical software (Ferreira, 2009).

\section{Results and discussions}

Crambe plant height showed no significant difference related to nitrogen fertilization, corroborating Freitas (2010). However, significant differences were observed for phosphate fertilization and nitrogen interaction with phosphorus (Table 1). Results of the different treatments are shown in Figures 1.

It was observed that plant height varied linearly due to nitrogen doses with the application of 50 and $125 \mathrm{~kg} \mathrm{ha}^{-1} \mathrm{P}_{2} \mathrm{O}_{5}$ (Figure $1 \mathrm{~A}$ ), although it occurred in a decreasing and in an increasing rate to the dosages aforementioned, respectively. It can probably be explained by Liebig's law, that is, "plant growth will be impaired by the element that is in a lower concentration than that required by the plant." Thus, the $50 \mathrm{~kg} \mathrm{ha}^{-1} \mathrm{P}_{2} \mathrm{O}_{5}$ dose may not have been sufficient to improve crambe development, although increasing nitrogen doses were applied to the soil. When the highest $\mathrm{P}_{2} \mathrm{O}_{5}$ dose was applied along with nitrogen doses, plant growth was favored. Nitrogen interaction with other $\mathrm{P}_{2} \mathrm{O}_{5}$ doses $(0,75$ and $100 \mathrm{~kg} \mathrm{ha}^{-1}$ ) had no significant effect on plant height, in which means of $0.51 \mathrm{~m}, 0.55 \mathrm{~m}$ and $0.53 \mathrm{~m}$, respectively, were obtained. 
Table 1 - Analysis of variance for crambe plant height $(\mathrm{PH})$, number of branches (NB) and plant dry matter (PDM) according to nitrogen and $\mathrm{P}_{2} \mathrm{O}_{5}$ doses.

\begin{tabular}{|c|c|c|c|c|}
\hline \multirow{2}{*}{ Variation source } & \multirow{2}{*}{$\begin{array}{l}\text { Degree of } \\
\text { freedom }\end{array}$} & \multicolumn{3}{|c|}{ Mean Square } \\
\hline & & $\mathrm{PH}$ & NB & PDM \\
\hline Block & 2 & $0.008^{* *}$ & $2.02^{*}$ & $1.03^{\text {ns }}$ \\
\hline Nitrogen $(\mathrm{N})$ & 4 & $0.002^{\text {ns }}$ & $2.67^{\star \star}$ & $7.96^{\star *}$ \\
\hline Linear & 1 & $0.003^{\text {ns }}$ & $8.17^{* *}$ & $29.01^{* *}$ \\
\hline Quadratic & 1 & $0.002^{\text {ns }}$ & $0.73^{\text {ns }}$ & $0.34^{\mathrm{ns}}$ \\
\hline Phosphorus $\left(\mathrm{P}_{2} \mathrm{O}_{5}\right)$ & 4 & $0.006^{* *}$ & $3.89^{* *}$ & $0.45 \mathrm{~ns}$ \\
\hline Linear & 1 & $0.013^{* *}$ & $3.24^{\mathrm{ns}}$ & $0.004^{\mathrm{ns}}$ \\
\hline Quadratic & 1 & $0.002^{\text {ns }}$ & $5.81^{* *}$ & $0.016^{\mathrm{ns}}$ \\
\hline $\mathrm{N} \times \mathrm{P}_{2} \mathrm{O}_{5}$ & 16 & $0.006^{* *}$ & $0.85^{\mathrm{ns}}$ & $1.77 \mathrm{~ns}$ \\
\hline \multicolumn{5}{|l|}{$\mathrm{N}$ within $\mathrm{P}_{2} \mathrm{O}_{5}(2)$} \\
\hline Linear & 1 & $0.014^{* *}$ & $6.35 \mathrm{~ns}$ & $3.38 \mathrm{~ns}$ \\
\hline \multicolumn{5}{|l|}{$\mathrm{N}$ within $\mathrm{P}_{2} \mathrm{O}_{5}(5)$} \\
\hline Linear & 1 & $0.0108^{* *}$ & $4.03 \mathrm{~ns}$ & $5.16 \mathrm{~ns}$ \\
\hline \multicolumn{5}{|l|}{$\mathrm{P}_{2} \mathrm{O}_{5}$ within $\mathrm{N} 4$} \\
\hline Linear & 1 & $0.035^{* *}$ & $5.39 \mathrm{~ns}$ & $3.12 \mathrm{~ns}$ \\
\hline Residue (S) & 48 & 0.002 & 0.47 & 1.57 \\
\hline CV (\%) & & 8.34 & 10.07 & 16.22 \\
\hline General mean & & $0.54 \mathrm{~m}$ & 6.83 & $7.73 \mathrm{~g}$ \\
\hline
\end{tabular}

${ }^{*},{ }^{* *}$ : Significant at 5 and $1 \%$ error probability, respectively; ${ }^{\text {ns: }}$ not significant

(A)

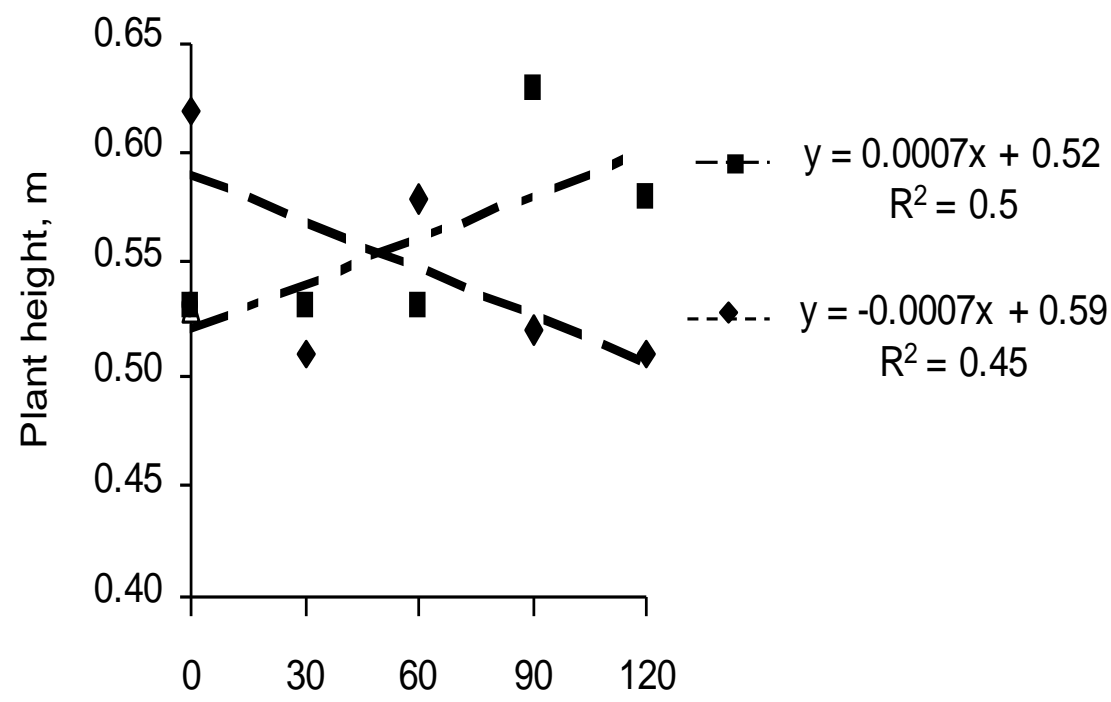

Nitrogen Doses, $\mathrm{kg} \mathrm{ha}^{-1}$
(B)

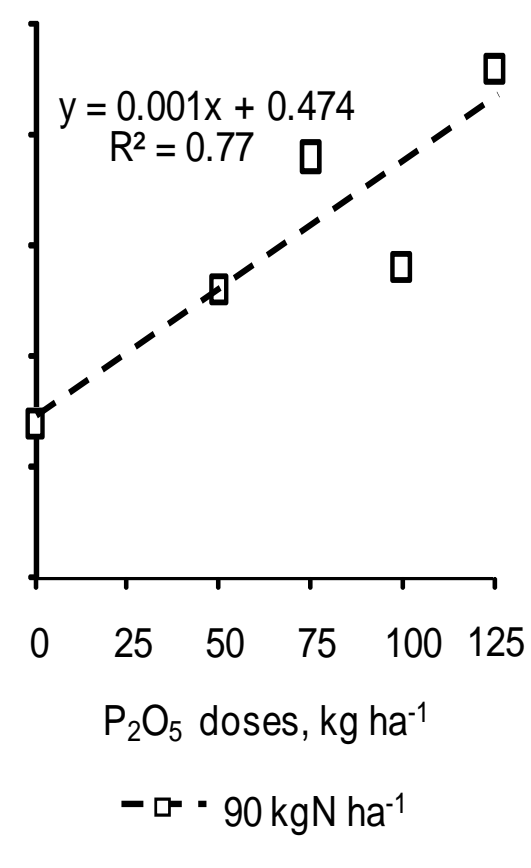

Figure 1 - Crambe plant height related to the interaction between nitrogen and $\mathrm{P}_{2} \mathrm{O}_{5}$ doses $(A)$ and $\mathrm{P}_{2} \mathrm{O}_{5}$ and nitrogen doses (B). 
Under this experiment conditions, mean plant height was of $54 \mathrm{~cm}$, corroborating with Viana (2013), who found plant height of $65 \mathrm{~cm}$ with sowing in July. In addition, equation determination coefficients in Figure $1 \mathrm{~A}$ were around 0.4, showing a low ratio between plant height and nitrogen doses applied on plots that received phosphate fertilizer.

Plant height increased linearly due to $\mathrm{P}_{2} \mathrm{O}_{5}$ doses interaction with the $90 \mathrm{~kg} \mathrm{ha}^{-1}$ nitrogen dose (Figure 1B). Other interactions, i.e., 0; 30; 60 and $125 \mathrm{~kg} \mathrm{ha}^{-1} \mathrm{~N}$, did not significantly influence plant height, and means of $0.54 \mathrm{~m}, 0.56 \mathrm{~m}, 0.54 \mathrm{~m}$ and $0.52 \mathrm{~m}$, respectively, were obtained. In some studies, such as the study by Nakagawa et al. (2001) with

(A)

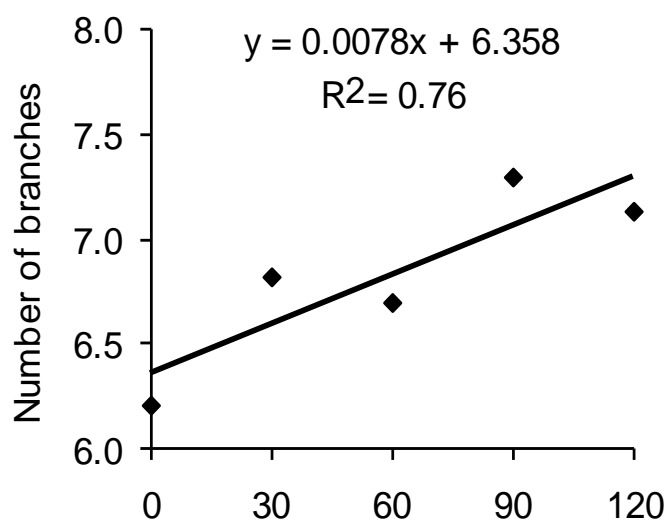

Nitrogen Doses, $\mathrm{kg} \mathrm{ha}^{-1}$ black oat, the main stem panicle length increased with increasing phosphorus doses, and a higher value was obtained at the highest dose, what corroborates with results observed for crambe height.

The number of branches was significantly influenced by nitrogen and $\mathrm{P}_{2} \mathrm{O}_{5}$ increasing doses (Table 1), as these elements, according to Malavolta et al. (1997), are essential to plant growth. As the nitrogen applied to the soil increased, the number of branches increased linearly. However, quadratic behavior was observed in $\mathrm{P}_{2} \mathrm{O}_{5}$ treatments, and the best dose of this element to increase the number of branches was of $62.5 \mathrm{~kg} \mathrm{ha}^{-1}$ (Figure 2).

(B)

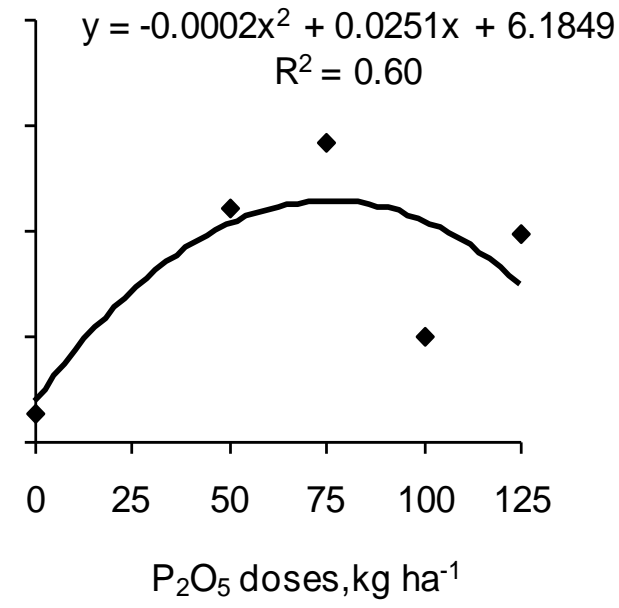

Figure 2 - Number of crambe branches related to nitrogen $(A)$ and $\mathrm{P}_{2} \mathrm{O}_{5}(B)$ doses.

Crambe dry matter increased linearly according to nitrogen doses (Figure 3), which was mainly caused by increased number of branches, as shown in Figure 3. This significant effect on plant dry matter was also observed by Broch et al. (2010) and Tomassoni (2015). Contrary to what was observed by Rogério et al. (2012), phosphate fertilizer did not significantly influence crambe dry matter in this study, corroborating with Lavagnolli \& Silva (2009). This was probably due to the initial $\mathrm{P}_{2} \mathrm{O}_{5}$ content in the soil, 18.8 $\mathrm{mg} \mathrm{dm}^{-3}$, a level considered regular.

The number of siliques per crambe plant was significantly influenced by nitrogen and phosphate fertilizers, in addition to the interaction between both nutrients (Table 2).

The behavior of number of siliques related to nitrogen interaction with $\mathrm{P}_{2} \mathrm{O}_{5}$ doses can be observed in Figure 4. The number of siliques increased linearly in relation to increasing nitrogen doses along with the highest $\mathrm{P}_{2} \mathrm{O}_{5}$ dose, while the $75 \mathrm{~kg} \mathrm{ha}^{-1} \mathrm{P}_{2} \mathrm{O}_{5}$ dose was quadratic. Nitrogen, in addition to being the most required nutrient by crops (essential for plant growth and development), influences the synthesis metabolism of seed stock compounds (Castro et al, 1999), also influencing the number of siliques. According to
Soratto et al. (2013), who evaluated crambe crop NPK, the number of siliques per plant was higher with the highest $\mathrm{N}, \mathrm{P}_{2} \mathrm{O}_{5}$ and $\mathrm{K}_{2} \mathrm{O}$ (8:28:16) dose, $300 \mathrm{~kg} \mathrm{ha}^{-1}$.

$\mathrm{P}_{2} \mathrm{O}_{5}$ interactions with 0,90 and $120 \mathrm{~kg} \mathrm{ha}^{-1}$ nitrogen doses were significant (Table 2). However, the behavior of these interactions are not shown in the graphs, as correlation values were low, i.e., below 0.31 . Still, it is important to note in this paper that the highest number of siliques, around 500 , was obtained with the highest $\mathrm{P}_{2} \mathrm{O}_{5}$ dose, $125 \mathrm{~kg} \mathrm{ha}^{-1}$, along with 120 $\mathrm{kg} \mathrm{ha}^{-1}$ nitrogen. Phosphorus, essential element for plant metabolism, influenced the number of siliques, since this nutrient, among various functions, stimulates flowering and seed formation, increasing yield (Malavolta et al., 1997).

Crambe 1000-grain weight, yield and oil, nitrogen and protein contents in grains were not affected by nitrogen and phosphorus doses, in accordance with Soratto et al. (2013). Mean 1000-grain weight was of $6.06 \mathrm{~g}$, in accordance with Viana (2013), who found $6.33 \mathrm{~g}$ in crambe planting held in July, in the municipality of Cascavel, Paraná. The yield observed by Viana (2013) was higher than that observed in this study, 530.73 and $166.34 \mathrm{~kg} \mathrm{ha}^{-1}$ respectively. 


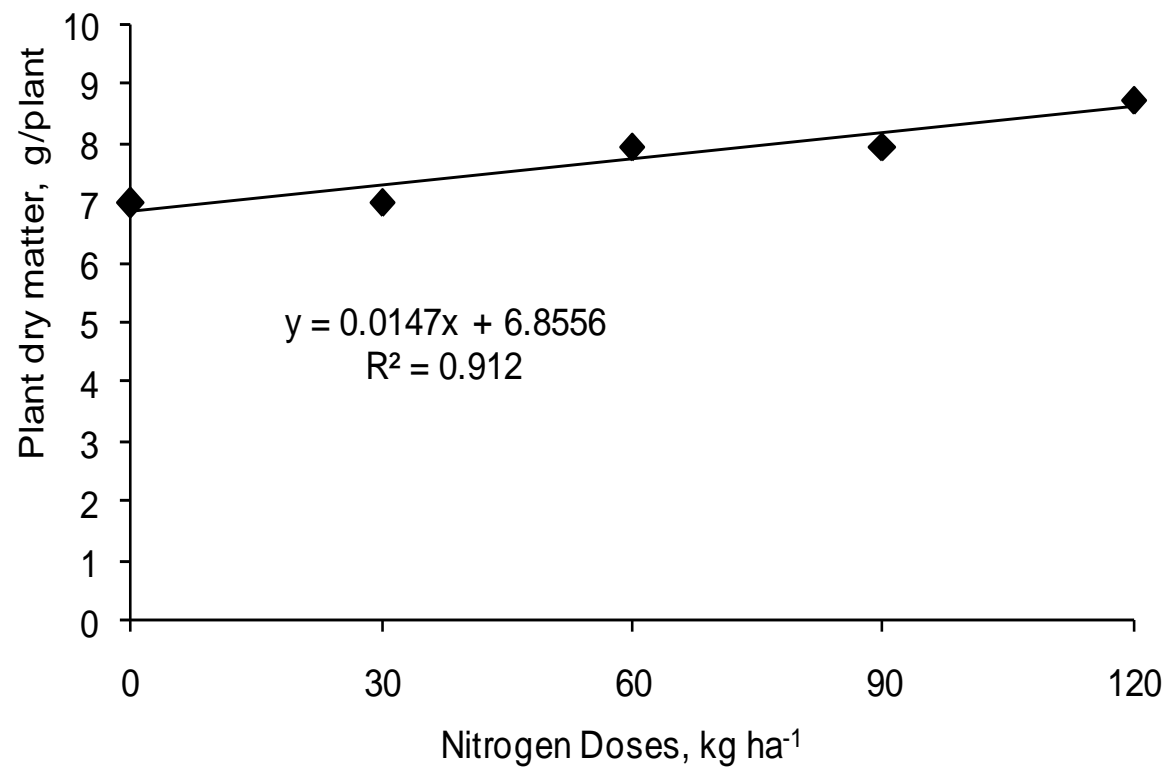

Figure 3 - Crambe dry matter according to nitrogen doses.

Table 2 - Analysis of variance for number of siliques (NS), 1,000-grain weight (1000GW) and yield (YIELD) for different nitrogen and $\mathrm{P}_{2} \mathrm{O}_{5}$ fertilizer doses for crambe.

\begin{tabular}{|c|c|c|c|c|}
\hline \multirow{2}{*}{ Variation source } & \multirow{2}{*}{$\begin{array}{l}\text { Degree of } \\
\text { freedom }\end{array}$} & \multicolumn{3}{|c|}{ Mean Square } \\
\hline & & NS & 1000GW & YIELD \\
\hline Block & 2 & $59865.70^{* *}$ & $0.303^{\text {ns }}$ & 27.03 ns \\
\hline Nitrogen $(\mathrm{N})$ & 4 & $13036.94^{* *}$ & $0.118^{\text {ns }}$ & $8761.73^{\mathrm{ns}}$ \\
\hline Quadratric & 1 & $12129.60^{\star *}$ & 0.312 & $792.68^{\mathrm{ns}}$ \\
\hline Phosphorys $\left(\mathrm{P}_{2} \mathrm{O}_{5}\right)$ & 4 & $13919.00^{* *}$ & $0.186^{\text {ns }}$ & $8350.95^{\mathrm{ns}}$ \\
\hline Linear & 1 & $29486.60^{* *}$ & $0.337^{\mathrm{ns}}$ & $5286.48^{\mathrm{ns}}$ \\
\hline $\mathrm{N} \times \mathrm{P}_{2} \mathrm{O}_{5}$ & 16 & $14608.36^{* *}$ & $0.133^{\text {ns }}$ & $7477.45^{\mathrm{ns}}$ \\
\hline \multicolumn{5}{|l|}{$\mathrm{N}$ within $\mathrm{P}_{2} \mathrm{O}_{5}$ (3) } \\
\hline Quadratric & 1 & $12848.50^{* *}$ & $0.074 \mathrm{~ns}$ & $2151.44 \mathrm{~ns}$ \\
\hline \multicolumn{5}{|l|}{$\mathrm{N}$ within $\mathrm{P}_{2} \mathrm{O}_{5}(4)$} \\
\hline Linear & 1 & $24722.18^{* *}$ & $1.200 \mathrm{~ns}$ & $8869.01 \mathrm{~ns}$ \\
\hline \multicolumn{5}{|l|}{$\mathrm{N}$ within $\mathrm{P}_{2} \mathrm{O}_{5}(5)$} \\
\hline Linear & 1 & $114651.37^{\star \star}$ & $0.088 \mathrm{~ns}$ & $44191.50 \mathrm{~ns}$ \\
\hline \multicolumn{5}{|l|}{$\mathrm{P}_{2} \mathrm{O}_{5}$ within $\mathrm{N} 1$} \\
\hline Quadratic & 1 & 9288.34 * & $0.187 \mathrm{~ns}$ & $15641.92 \mathrm{~ns}$ \\
\hline \multicolumn{5}{|l|}{$\mathrm{P}_{2} \mathrm{O}_{5}$ within $\mathrm{N} 4$} \\
\hline Linear & 1 & $21329.74^{\star *}$ & $0.103 \mathrm{~ns}$ & 4494.65ns \\
\hline \multicolumn{5}{|l|}{$\mathrm{P}_{2} \mathrm{O}_{5}$ within $\mathrm{N} 5$} \\
\hline Linear & 1 & $27466.73^{* *}$ & $0.154 \mathrm{~ns}$ & $41292.97 n s$ \\
\hline Quadratic & 1 & $8029.27^{*}$ & $0.062 \mathrm{~ns}$ & $906.03 n s$ \\
\hline Residue (S) & 48 & 1383.23 & 0.155 & 4967.01 \\
\hline CV (\%) & & 11.21 & 6.51 & 42.37 \\
\hline General mean & & 331.76 & $6.06 \mathrm{~g}$ & $166.34 \mathrm{~kg}$ \\
\hline
\end{tabular}

${ }^{*},{ }^{* *}$ : Significant at 5 and $1 \%$ error probability, respectively; ${ }^{\text {ns: }}$ not significant. 


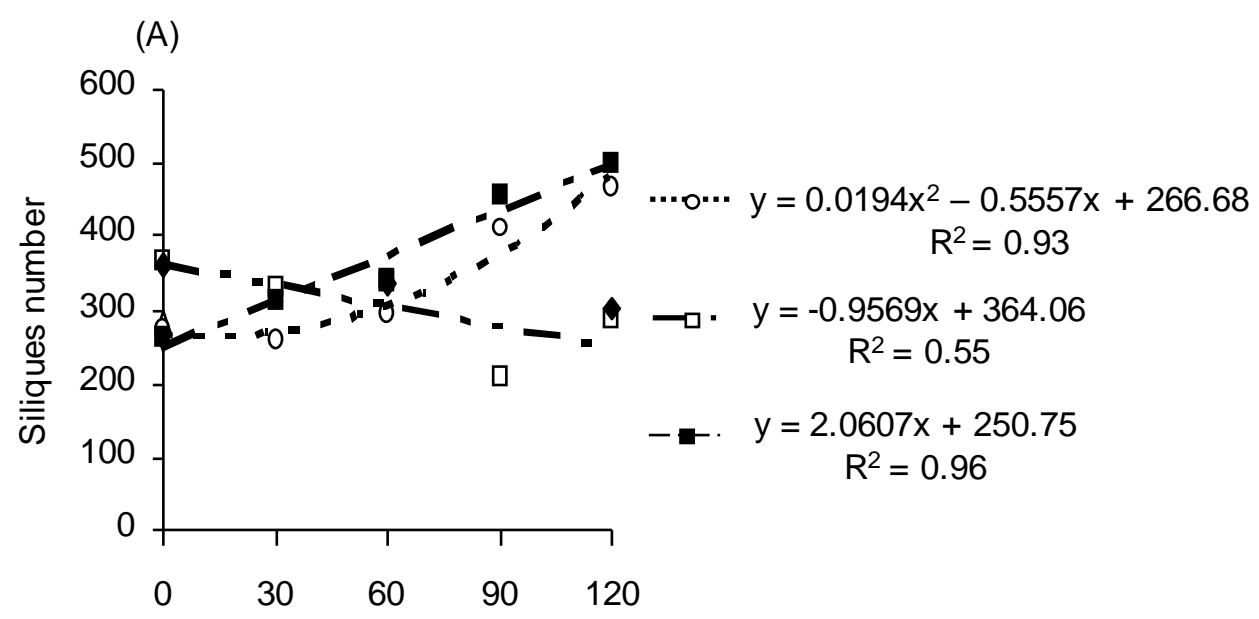

Nitrogen Doses, $\mathrm{kg} \mathrm{ha}^{-1}$

$\cdots$ o. $75 \mathrm{kgP}_{2} \mathrm{O}_{5} \mathrm{ha}^{-1} \longrightarrow \cdot 100 \mathrm{kgP}_{2} \mathrm{O}_{5} \mathrm{ha}^{-1}$

- $125 \mathrm{kgP}_{2} \mathrm{O}_{5} \mathrm{ha}^{-1}$

Figure 4 - Number of crambe siliques in relation to the interaction between nitrogen and $\mathrm{P}_{2} \mathrm{O}_{5}$ doses.

The rainfall factor contributed to the poor results of the variables, as there was no rain in August, in addition to a storm close to harvest time. Both events damaged the number of branches, plant dry matter, number of siliques and crambe yield.

Thermal and water stress, according to Souza et al. (2010), cause increased flower abortion, reduced nutrient availability in the soil and lower grain yield, noting that the crop no longer needs water from grain filling, i.e., high rainfall at this period cause reduced yield. Seed amount may be influenced by soil fertility and rain in the production period (Desai et al., 1997). Similarly, Luz (2011), while performing experiments with canola in the south of Brazil, at different planting times, found that the highest yield occurred in the period between
April 3 to June 12, taking into account that yield fell sharply from June 26. Viana (2013) found that crambe production is lower when planting is conducted in July; between April to June, results were much more satisfactory.

Similar results were observed in experiments conducted by Pitolet et al. (2010b), in different locations in the states of Mato Grosso do Sul, Goiás and Mato Grosso; sowing conducted during April showed better results in crambe development and yield than sowing conducted in May; it was observed that late sowing resulted in reduced yield.

Nitrogen doses application in crambe planting significantly influenced foliar potassium levels (Table 3), which increased linearly in relation to the treatments (Figure 5).

Table 3 - Analysis of variance for nitrogen (foliar N), phosphorus (foliar $\mathrm{P}$ ) and potassium (foliar K) contents in relation to nitrogen and $\mathrm{P}_{2} \mathrm{O}_{5}$ doses for crambe.

\begin{tabular}{|c|c|c|c|c|}
\hline \multirow{2}{*}{ Variation source } & \multirow{2}{*}{ Degree of freedom } & \multicolumn{3}{|c|}{ Mean square } \\
\hline & & Foliar N & Foliar $\mathrm{P}$ & Foliar K \\
\hline Block & 2 & 105.23 ns & $0.61^{\mathrm{ns}}$ & $88.44^{\star *}$ \\
\hline Nitrogen $(\mathrm{N})$ & 4 & $69.21 \mathrm{~ns}$ & $0.24^{\text {ns }}$ & $32.41^{*}$ \\
\hline Linear & 1 & $187.35^{\text {ns }}$ & $0.02^{\text {ns }}$ & $93.93^{* *}$ \\
\hline Phosphorus $\left(\mathrm{P}_{2} \mathrm{O}_{5}\right)$ & 4 & $181.54^{\text {ns }}$ & $0.27^{\mathrm{ns}}$ & $3.70^{\text {ns }}$ \\
\hline $\mathrm{N} \times \mathrm{P}_{2} \mathrm{O}_{5}$ & 16 & $158.55^{\mathrm{ns}}$ & $0.20^{\mathrm{ns}}$ & $14.56^{\text {ns }}$ \\
\hline Residue (S) & 48 & 87.30 & 0.37 & 8.68 \\
\hline CV (\%) & & 34.79 & 32.47 & 11.41 \\
\hline General mean & & $26.86 \mathrm{~g} \mathrm{~kg}^{-1}$ & $1.87 \mathrm{~g} \mathrm{~kg}^{-1}$ & $25.82 \mathrm{~g} \mathrm{~kg}^{-1}$ \\
\hline
\end{tabular}




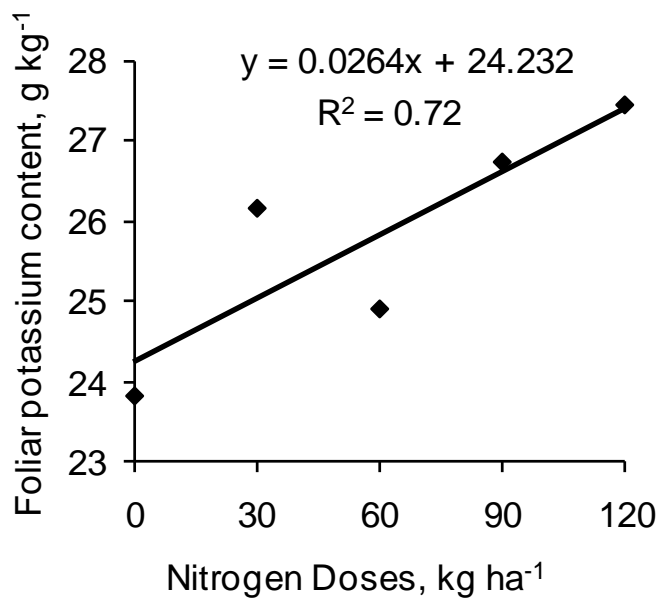

Figure 5 - Foliar potassium content with increasing nitrogen doses.

Foliar nitrogen contents ranged from 23.55 to $28.79 \mathrm{~g} \mathrm{~kg}^{-1}$ and from 28.62 to $29.04 \mathrm{~g} \mathrm{~kg}^{-1}$ in relation to nitrogen and phosphorus treatments, respectively. Regarding foliar phosphorus content, they ranged from 1.91 to $2.00 \mathrm{~g} \mathrm{~kg}^{-1}$ and from 1.70 to $2.06 \mathrm{~g} \mathrm{~kg}^{-1}$ in relation to nitrogen and phosphorus treatments, respectively. Finally, foliar potassium content varied from 26.03 to $26.33 \mathrm{~g} \mathrm{~kg}^{-1}$ in relation to phosphorus treatments. However, although these values apparently increased in relation to the treatment, these variations were not significantly affected by the treatments applied to the soil. In the same way, nitrogen and phosphorus interaction did not influence foliar NPK contents. This probably occurred due to the dilution effect of the elements in the leaf part, which is caused by increased dry matter production. According to Soratto et al. (2013), NPK fertilization did not affect foliar nitrogen and potassium contents, and similar results to the data aforementioned were found in their study.

In general, the experiment conducted in the period from July to November 2012 had no good development due to climatic conditions. In August, there was a drought that could be resolved by irrigation. In addition, there was a storm in the planting area a few days before harvest, causing threshing, which affected crop yield. Moreover, crambe crop was also impaired because the planting season occurs later.

\section{Conclusions}

Increased nitrogen doses in the soil increased the number of branches, plant dry matter, number of siliques and foliar potassium content.

Phosphorus application in the soil increased plant height, number of branches $\left(75 \mathrm{~kg} \mathrm{ha}^{-1}\right)$ and the number of siliques.

In general, nitrogen and phosphorus interaction positively influenced plant height and the number of siliques.

Foliar nitrogen and phosphorus were not affected by nitrogen and phosphorus application in soil.

\section{References}

Broch DL, Ranno SK, Roscoe R (2010) Efeito de adubações de plantio e cobertura sobre a produtividade de crambe cv. FMS Brilhante após soja e milho. In: Congresso Brasileiro de Mamona, 4; Simpósio Internacional de Oleaginosas Energéticas, 1., João Pessoa, Anais...Campina Grande: Embrapa Algodão, p.652-657, 2010.

Castro C, Balla A, Castiglioni VBR (1999) Doses e métodos de aplicação de nitrogênio em girassol. Scientia Agrícola 56(4): 827-833.

Desai BB,Kotecha PM, Salunkhe DK (1997) Seeds handbook: biology, production processing and storage. Marcel Dekker. 627p.

Embrapa - Empresa Brasileira de Pesquisa Agropecuária (2009) Manual de análises químicas de solos, plantas e fertilizantes. 2 ed. Embrapa Informação Tecnológica.627p.

Falasca SL, Lamas MC, Carballo SM, Anschau A (2010)Crambeabyssinica: Analmostunknowncropwith a promissory future toproduce biodiesel inArgentina. International Journal of Hydrogen Energy 35(11):5808-5812.

Ferreira DF (2009) Estatística básica. 2. ed. UFLA. $664 p$.

Freitas MEE (2010) Comportamento agronômico da cultura do crambe (Crambeabyssinicahoechst) em função do manejo empregado. UFGD (Dissertação de Mestrado em Produção Vegetal).

Knights EG (2002) Crambe: A North Dakota case study. A report for the rural industries research and development corporation. RIRDC Publication No. W02/005. 25p.

Lavagnolli RF, Silva TRB (2009) Efeito da adubação com fósforo e zinco na cultura do crambe. Faculdade Assis Gurgacz (Monografia de graduação em Agronomia). 
Luz GL (2011) Exigência térmica e produtividade de canola em diferentes épocas de semeadura em Santa Maria.UFSM (Tese de doutorado em Agronomia).

Malavolta E, Vitti GC, Oliveira SA (1997) Avaliação do estado nutricional de plantas: princípios e aplicações. Potafos. 308p.

Medeiros G (2007) Empresas incentivam plantio de crambe para biodiesel. Disponível em: < http://www.matima.com.br/energia/blog_commento.a $\mathrm{sp}>$ (Acesso em 31 jul 2011).

Nakagawa J,Cavariani C, Bicudo SJ (2001)Produção e qualidade de sementes de aveia-preta em função da adubação fosfatada e potássica. Revista Brasileira de Sementes 23(1):260-266.

Pitol C (2008) Cultura do Crambe. In: Tecnologia e Produção: Milho Safrinha e Culturas de Inverno. Disponível em:

$<$ http://www.agroprecisa.com.br/site/noticias/download/crambe-cultivoms.pdf>(Acesso em 31 jul 2011).

Pitol C,Broch DL,Roscoe R (2010a)Tecnologia e Produção: Crambe 2010. Fundação MS. 60p.

Pitol C,Broch DL,Roscoe R (2010b) Tecnologia e Produção: Crambe. In: Broch DL, Roscoe R (ed) Fertilidade do solo, adubação e nutrição do crambe. Fundação MS. p. 22-36.
Rogério F, Santos JI, Silva TRB, Migliavacca RA, Gouveia B, Barbosa MC (2012) Efeito de doses de fósforo no desenvolvimento da cultura do crambe. Bioscience Journal 28 (sup.1): 251-255.

Soratto RP, Souza-Schlick GD, Fernandes AM, Souza EFC (2013) Effect of fertilization at sowing on nutrition and yield of crambe in second season. Revista Brasileira Ciência do Solo 37(3):658-666.

Souza TAF, Raposo RWC, Dantas AJA, Silva CV, Gomes Neto AD, Santos LCN, Araujo RCA, Rodrigues HRN, Andrade DA, Medeiros DA, Dias JA, Silva ES, Lima GK, Lucena EHL,Prates CSF (2010) Produção de grãos de canola em função de épocas de semeadura em dois anos de cultivo.In:Congresso Brasileiro de Mamona, 4 \& Simpósio Internacional de Oleaginosas Energéticas, 1, 2010, João Pessoa. Inclusão Social e Energia: Anais... Campina Grande: Embrapa Algodão. p.1454-1458.

Tomassoni F (2015) Aplicação de nitrogênio no crambe cultivado após culturas de cobertura. UNIOEST (Dissertação do Mestrado em Energia na Agricultura).

Viana $\mathrm{OH}$ (2013) Cultivo do crambe na Região Oeste do Paraná. UNIOESTE (Dissertação de mestrado em Energia na Agricultura). 